\title{
Pebapomberus, a new orthoclad genus from Brazil (Diptera: Chironomidae, Orthocladiinae)
}

\author{
Humberto Fonseca Mendes ${ }^{1,3}$ \& Trond Andersen ${ }^{2}$ \\ ${ }^{1}$ Centro de Ciências Naturais e Humanas - CCNH, Universidade Federal do ABC - UFABC, \\ Bloco A, Av. dos Estados, 5001, Bangu, CEP 09210-580, Santo André, SP, Brazil \\ ${ }^{2}$ Department of Natural History, University Museum of Bergen, P.O. Box 7800, N-5020 Bergen, Norway \\ ${ }^{3}$ Corresponding author: Humberto Fonseca Mendes, e-mail: orthocladiinae@gmail.com
}

MENDES, H.F. \& ANDERSEN, T. Pebapomberus, a new orthoclad genus from Brazil (Diptera: Chironomidae, Orthocladiinae). Biota Neotrop. 12(2): http://www.biotaneotropica.org.br/v12n2/en/ abstract?article+bn00412022012

Abstract: The genus Pebapomberus gen. n. is erected for P. rugendas sp. n. from Santa Catarina and São Paulo States and P. euniceae sp. n., from São Paulo State. The genus is characterized by bare eyes without dorsomedian extension; anterior simple and posterior scalpellate, weak acrostichals; bare wing membrane; squama with few setae; large, wedge-shaped anal point; and gonostylus with large, flattened apical lobe.

Keywords: new species, Brazil, São Paulo State, Santa Catarina State, Neotropical region, Mata Atlântica.

MENDES, H.F. \& ANDERSEN, T. Pebapomberus, um gênero novo de Orthocladiinae do Brasil (Diptera: Chironomidae). Biota Neotrop. 12(2): http://www.biotaneotropica.org.br/v12n2/pt/ abstract?article+bn00412022012

Resumo: O gênero Pebapomberus gen. n. é descrito com base em P. rugendas sp. n. dos Estados de Santa Catarina e São Paulo e P. euniceae sp. n., de São Paulo. O gênero é caracterizado pelo olho sem microtríquios entre os omatídeos e extensão dorso-mediana do olho ausente; setas acrosticais fracas, sendo as anteriores simples e as posteriores escalpeladas; membrana alar sem setas; squama com poucas setas; ponta anal em forma de cunha e gonóstilo com um lobo apical grande e achatado.

Palavras-chave: espécie nova, Brasil, São Paulo, Santa Catarina, região Neotropical, Mata Atlântica. 


\section{Introduction}

In their catalog of the Neotropical and Mexican chironomids Spies \& Reiss (1996) recorded seven Orthocladiinae species from Brazil; one of these, Ichthyocladius neotropicus Fittkau, as uncertain, a species which later has proved not to occur in Brazil (Mendes et al. 2004). Today about 100 species of orthoclads have been described or recorded from Brazil and several new genera have been added (Mendes \& Pinho 2011). However, a high number of new species still await description. When collecting in Brazil many of the orthoclads encountered do not readily fit into any described genus. Several of these might be terrestrial or semiterrestrial and the larvae and pupae might be difficult to find. Below we describe the males of two of these species and place them in a new genus. Both species were collected in Mata Atlântica in South and Southeast Brazil.

\section{Material and Methods}

The specimens were mounted on slides in Canada balsam or Euparal following the procedures outlined by Sæther (1969). The terminology follows Sæther (1980).

The types are deposited in the Museu de Zoologia da Universidade de São Paulo, São Paulo, Brazil (MZUSP).

\section{Pebapomberus new genus}

Type species: Pebapomberus rugendas sp. n., by present designation.

Other included species: Pebapomberus euniceae sp. n.

Etymology: From Tupy "peb", "po", and "mberui" meaning flat, hand, and midge, referring to the shape of the gostylus. The gender of the name is masculine.

Diagnostic characters: The combination of bare eyes without dorsomedian extension; anterior simple and posterior scalpellate, weak acrostichals; bare wing membrane; squama with few setae, large wedge-shaped anal point, and gonostylus with large, flattened apical lobe will separate the genus from all other Orthocladiinae

\section{Description}

Small sized species, wing length 1.1-1.3 mm.

Head. Eye bare, reniform, without dorsomedian extension. Male antenna with 13 flagellomeres; groove beginning on flagellomere 3; sensilla chaetica present on flagellomeres 2, 3 and ultimate; ultimate flagellomere slightly swollen subapically, tapering, without subapical seta; AR 0.7-0.9. Palpomeres normal, third palpomere with few sensilla clavata subapically. Temporal setae in partly double row, inner verticals weak, outer verticals and postorbitals strong. Frontal tubercle absent, but with small, pale scar. Tentorium and stipes normal. Cibarial pump with anterior margin nearly straight. Clypeus with few setae.

Thorax. Antepronotum well developed with lobes meeting medially at anterior margin of scutum, with few lateral antepronotal. Acrostichals weak, starting close to antepronotum, anterior acrostichals simple, posterior acrostichals scalpelate; dorsocentrals simple, uniserial; prealars uniserial, grouped in posterior and anterior prealars; supraalar present. Scutellum with few setae in single row.

Wing. Membrane without setae, with fine punctuation. Anal lobe normal. Costa extended; $\mathrm{R}_{2+3}$ running and ending midway between $\mathrm{R}_{1}$ and $\mathrm{R}_{4+5} ; \mathrm{R}_{4+5}$ ending opposite to or distal to $\mathrm{M}_{3+4} ; \mathrm{FCu}$ distal to $\mathrm{RM} ; \mathrm{Cu}_{1}$ slightly sinuous. Brachiolum with 1 seta, $\mathrm{C}$ without or with few non-marginal setae, other veins bare. Squama with few setae. Sensilla campaniformia about 8 basally, 10 apically, and 3 above seta on brachiolum; 1 on RM; and 1 basally on $\mathrm{R}_{1}$.

Leg. Tibial spurs and comb normal. Tarsal pseudospurs and sensilla chaetica absent. Pulvilli vestigial.
Abdomen. Tergite I with few lateral setae, tergites II with anterior and posterior row of setae, tergites III-VIII with more scattered setae. Sternites I-III bare, sternites IV-V with single to few median setae, sternites VI-VII with more median setae, sternite VIII with more scattered setae.

Hypopygium. Anal point large, wedge-shaped with rounded apex, reaching below posterior margin of tergite IX, with microtrichia and weak, lateral setae. Tergite IX without seta; laterosternite IX with several setae. Phallapodeme normal; transverse sternapodeme curved, with well developed oral projections. Virga consisting of two separate, strong sclerites. Inferior volsella with anterior small bluntly rounded to larger, narrowly triangular, pointed lobe and posterior broadly rounded lobe with few marginal setae. Superior volsella barely indicated. Gonostylus broad, with large, apical, bluntly triangular to rounded, flattened lobe covered with macrotrichia and with few scattered setae; megaseta normal.

Female, pupa and larva. Unknown.

Systematics

This genus will key to dichotomy 76 in Cranston et al. (1989) where it will not key further and to Antillocladius Sæther in Mendes \& Andersen (2008) and in Spies et al. (2009). This genus shows similarities with Lyrocladius Mendes et Andersen, from which it can be separated on the broader, wedge-shaped the anal point and the gonostylus bearing a large, flattened apical lobe.

Following the parsimony analysis presented by Mendes \& Andersen (2008), the new genus is placed among the genera Antillocladius, Bryophaenocladius Thienemann, Gymnometriocnemus Goetghebuer, Litocladius Mendes, Andersen et Sæther, and Lyrocladius.

\section{Pebapomberus rugendas sp. n. (Figures 1-10)}

Type material: Holotype male, Brazil: Santa Catarina State: São Bento do Sul, 26 ${ }^{\circ} 19^{\prime}$ 25.6”' S and 48 18' 26.5' W, 1316.x.2001, $660 \mathrm{~m}$ a.s.1., Malaise trap (Trilha Rugendas), M. V. Yamada (MZUSP). Paratypes: 1 male, São Paulo State: Estação Biológica Boracéia, Salesópolis, córrego Coruja, 18.ix.2007, light trap, C. G. Froehlich et al. (MZUSP); 1 male: same data as pervious except for: córrego Venerando, 12.xii.2001.

Diagnostic characters: This species can be separated from P. euniceae n. sp. by the inferior volsella having a small, knob-like anterior lobe and by the subtriangular apical lobe of the gonostylus.

Etymology: Named after the path, Rugendas, where the Malaise trap was standing. The name is to be regarded as a noun in apposition.

Description

Male ( $n=2-3$, except when otherwise stated). Total length $1.75-1.99 \mathrm{~mm}$. Wing length $1.17-1.26 \mathrm{~mm}$. Total length/wing length 1.44-1.70. Wing length/length of profemur 2.54-2.70.

Coloration. Thorax, head, antennal flagellum, and coxae brown; abdomen and legs uniformly light brown.

Head (Figures 1-2). AR 0.74-0.78. Ultimate flagellomere 281-299 $\mu \mathrm{m}$ long. Temporal setae 8-10 including 4-5 inner verticals, 2 outer verticals, and 2-3 postorbitals. Clypeus with 6-11 setae. Tentorium, stipes, and cibarial pump as in Figure 2. Tentorium 93-109 $\mu \mathrm{m}$ long, 18-23 $\mu \mathrm{m}$ wide. Stipes 93-102 $\mu \mathrm{m}$ long. Palp segment lengths (in $\mu \mathrm{m}$ ): 16-20, 29-36, 57-69, 74-84, 68-79. Third palpomere with 5 sensilla clavata in two groups subapically, longest 9-12 $\mu \mathrm{m}$ long.

Thorax (Figure 3). Antepronotum with 1-2 seta. Dorsocentrals 7-8; acrostichals 12-13, beginning close to antepronotum, composed of 8-10 anterior simple and 2-5 posterior scalpellate; prealars 3,2 posterior and 1 anterior; supraalar 1 . Scutellum with 4 setae. 


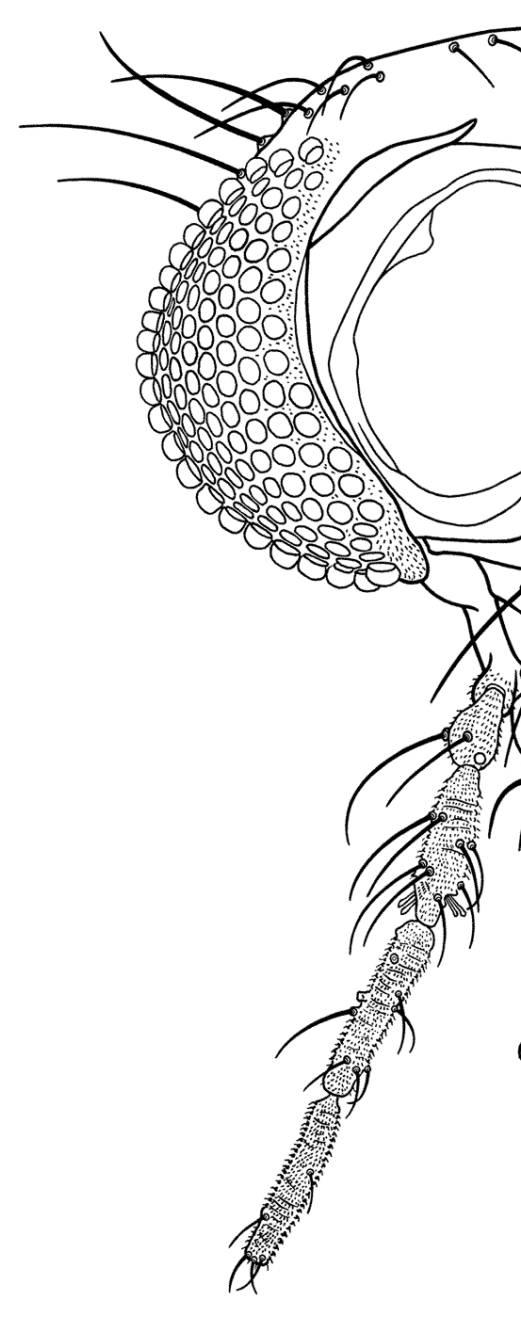

(1)
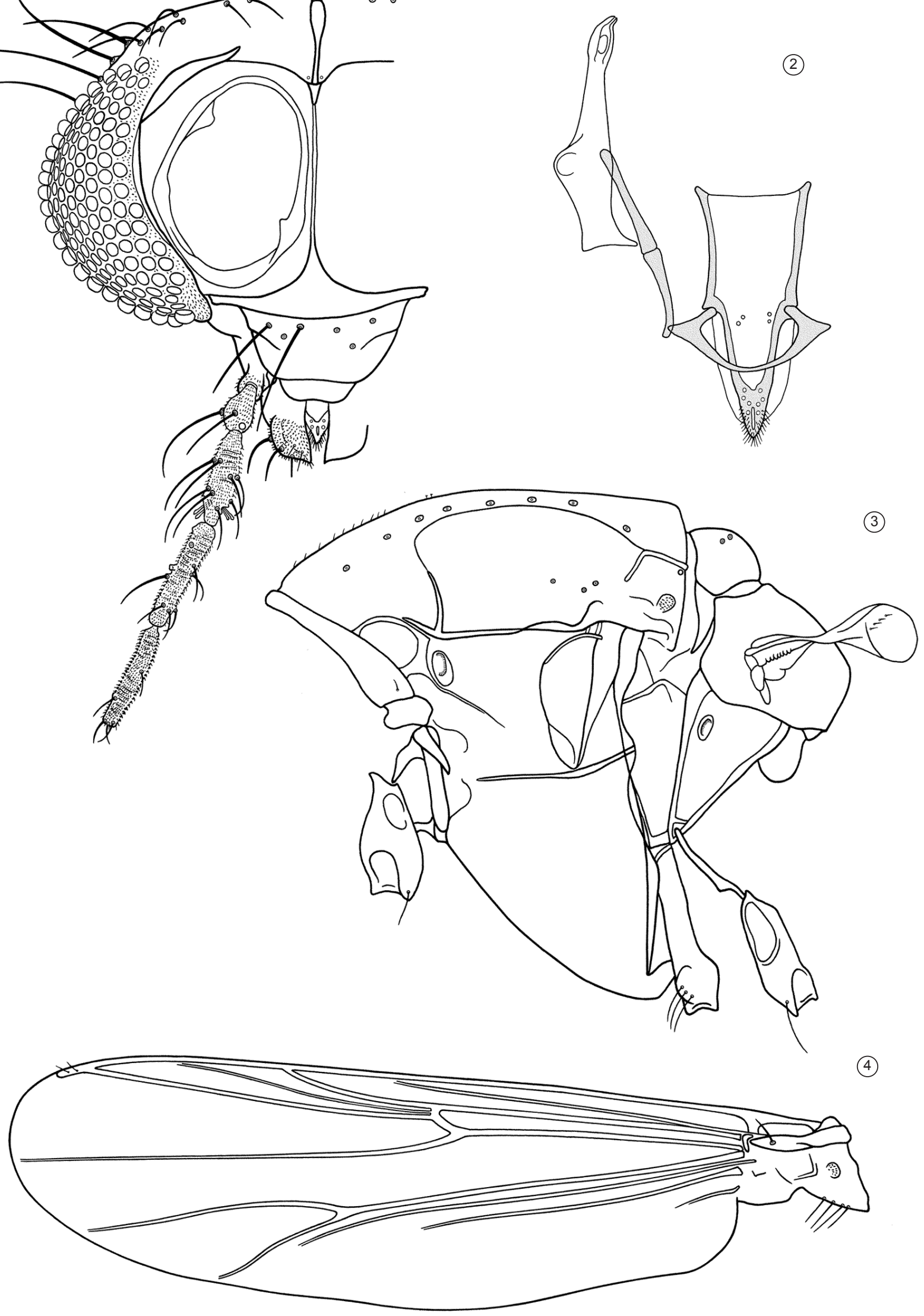

Figures 1-4. Pebapomberus rugendas sp. n., male. 1) Head; 2) Tentorium, stipes, and cibarial pump; 3) Thorax; 4) Wing. 


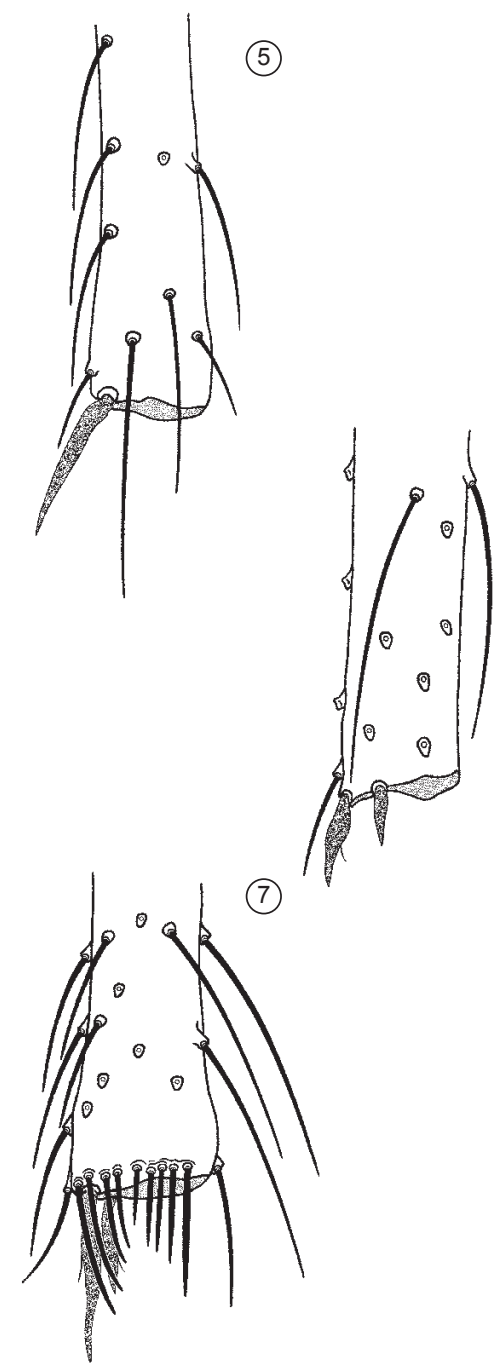

(6)

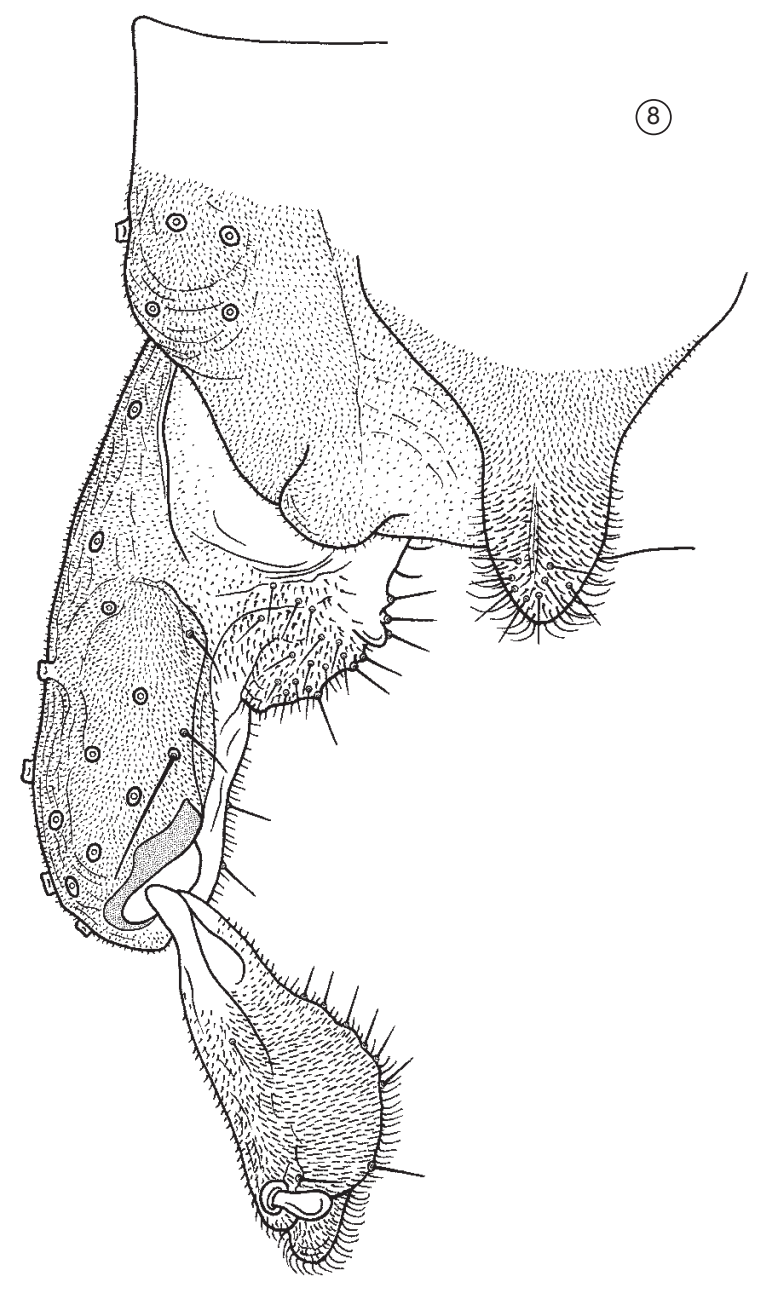

(9)

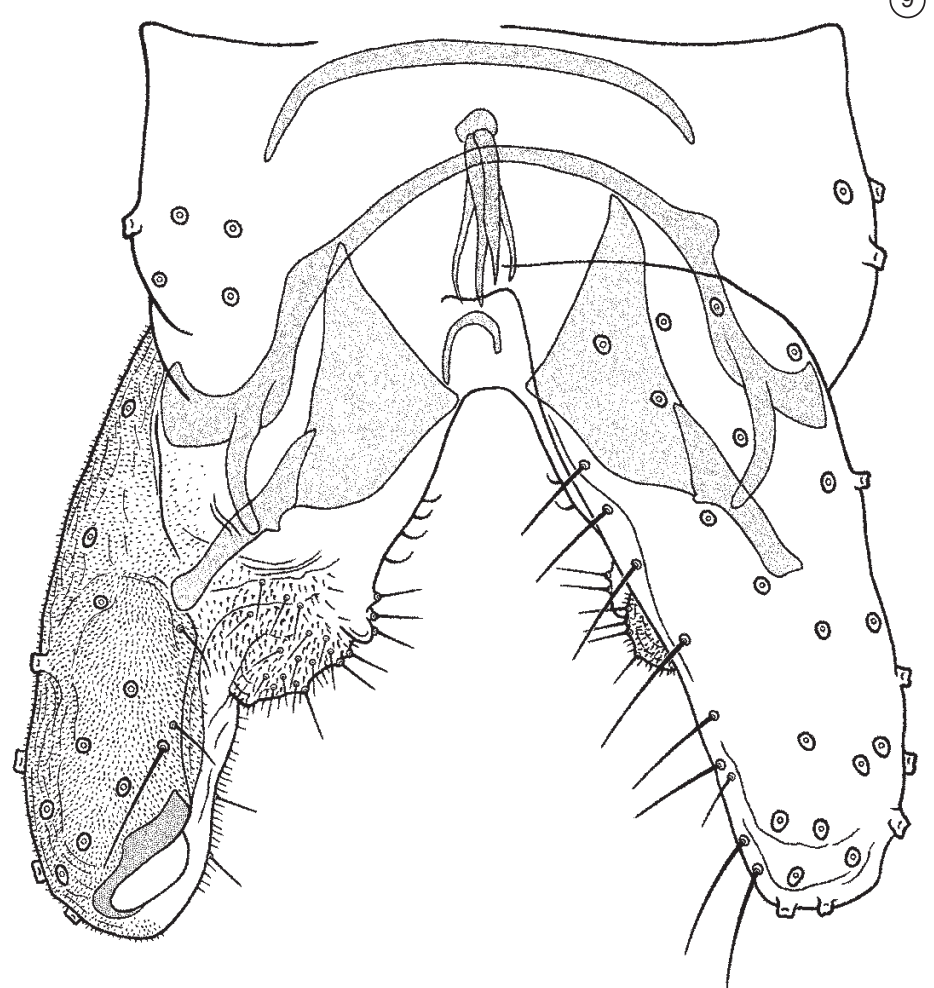

Figures 5-10. Pebapomberus rugendas sp. n., male. 5) Apex of fore tibia; 6) Apex of mid tibia; 7) Apex of hind tibia; 8) Hypopygium, dorsal view; 9) Hypopygium with anal point and tergite IX removed, dorsal aspect to the left and ventral aspect to the right; 10) flattened gonostylus, dorsal view. 

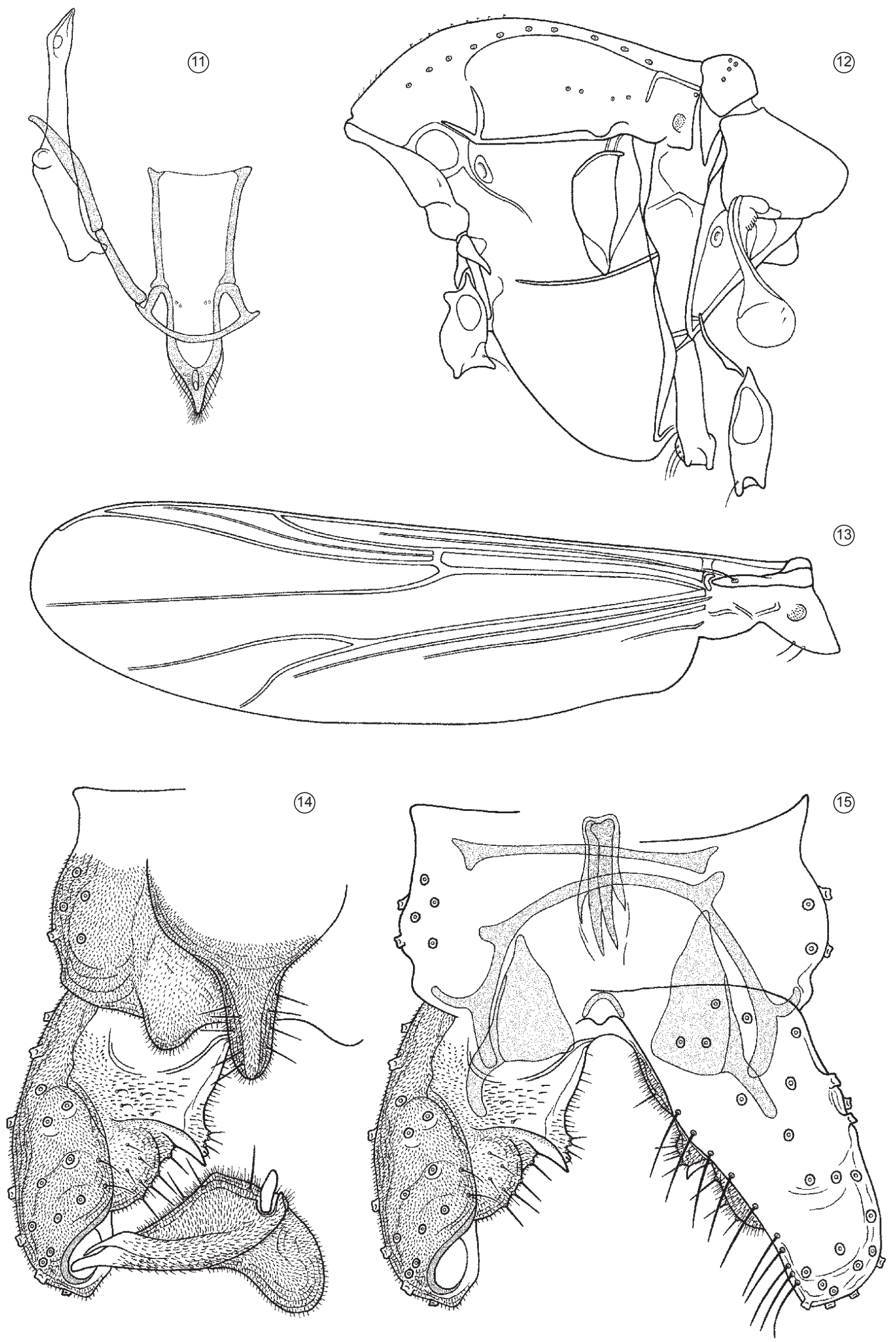

Figures 11-15. Pebapomberus euniceae sp. n., male. 11) Tentorium, stipes, and cibarial pump; 12) Thorax; 13) Wing; 14) Hypopygium, dorsal view; 15) Hypopygium with anal point and tergite IX removed, dorsal aspect to the left and ventral aspect to the right. 
Mendes, H.F. \& Andersen, T.

Table 1. Lengths (in $\mu \mathrm{m})$ and proportions of legs of Pebapomberus rugendas sp. n., male $(\mathrm{n}=2-3)$.

\begin{tabular}{ccccccccccccc}
\hline & $\mathbf{f e}$ & $\mathbf{t i}$ & $\mathbf{t a}_{\mathbf{1}}$ & $\mathbf{t a}_{\mathbf{2}}$ & $\mathbf{t a}_{\mathbf{3}}$ & $\mathbf{t a}_{\mathbf{4}}$ & $\mathbf{t a}_{\mathbf{5}}$ & $\mathbf{L R}$ & $\mathbf{B V}$ & $\mathbf{S V}$ & $\mathbf{B R}$ \\
\hline $\mathrm{p}_{1}$ & $425-482$ & $518-619$ & $281-295$ & $193-206$ & $133-140$ & $59-68$ & $41-43$ & $0.54-0.57$ & $2.85-2.89$ & $3.36-3.38$ & $2.5-3.0$ \\
$\mathrm{p}_{2}$ & $497-500$ & $465-468$ & $188-191$ & $104-112$ & $72-77$ & $37-43$ & $28-29$ & $0.40-0.41$ & $4.43-4.73$ & $5.06-5.07$ & $3.8-4.3$ \\
$\mathrm{p}_{3}$ & $511-554$ & $529-605$ & $292-338$ & $151-180$ & $144-156$ & $58-61$ & $40-43$ & $0.54-0.56$ & $3.48-3.52$ & $3.42-3.65$ & $3.9-6.0$ \\
\hline
\end{tabular}

Table 2. Lengths (in $\mu \mathrm{m}$ ) and proportions of legs of Pebapomberus euniceae sp. n., male $(\mathrm{n}=1)$.

\begin{tabular}{|c|c|c|c|c|c|c|c|c|c|c|c|}
\hline & fe & ti & $\mathbf{t a}_{1}$ & $\mathrm{ta}_{2}$ & $\mathbf{t a}_{3}$ & $\mathrm{ta}_{4}$ & $\mathrm{ta}_{5}$ & $\mathbf{L R}$ & BV & SV & BR \\
\hline $\mathrm{p}_{1}$ & 475 & 511 & 268 & 178 & 130 & 68 & 40 & 0.52 & 3.02 & 3.68 & 2.8 \\
\hline $\mathrm{p}_{2}$ & 508 & 461 & 184 & 101 & 79 & 47 & 32 & 0.40 & 4.44 & 5.27 & 3.3 \\
\hline $\mathrm{p}_{3}$ & 544 & 533 & 310 & 162 & 140 & 61 & 40 & 0.58 & 3.44 & 3.48 & 6.0 \\
\hline
\end{tabular}

Wing (Figure 4). VR 1.43-1.44. C extension 50-70 $\mu \mathrm{m}$ long. Brachiolum with 1 seta, $\mathrm{C}$ with 0-2 non-marginal setae, remaining veins and cells bare. Squama with 2-4 setae.

Legs (Figures 5-7). Spur of fore tibia 25-36 $\mu \mathrm{m}$ long, spurs of mid tibia 9-11 $\mu \mathrm{m}$ and 15-23 $\mu \mathrm{m}$, of hind tibia 14-16 $\mu \mathrm{m}$ and 36-40 $\mu \mathrm{m}$ long. Width at apex of fore tibia 24-32 $\mu \mathrm{m}$, of mid tibia 23-25 $\mu \mathrm{m}$, of hind tibia 35-39 $\mu \mathrm{m}$. Hind tibia comb with 9 (1) setae, longest 27 (1) $\mu \mathrm{m}$, shortest 14 (1) $\mu \mathrm{m}$ long. Lengths and proportions of legs as in Table 1.

Hypopygium (Figures 8-10). Tergite IX covered with microtrichia; laterosternite IX with 5-6 setae. Anal point wedge-shaped, 36-43 $\mu \mathrm{m}$ long, 20-34 $\mu \mathrm{m}$ wide at base, with 8-10 weak marginal setae. Phallapodeme 79-84 $\mu \mathrm{m}$ long; transverse sternapodeme $82 \mu \mathrm{m}$ long. Virga 41-48 $\mu \mathrm{m}$ long. Gonocoxite 138-148 $\mu \mathrm{m}$ long. Gonostylus $73 \mu \mathrm{m}$ long (not including apical lobe); megaseta 10-11 $\mu \mathrm{m}$ long. HR 2.00-2.03. HV 2.41-2.70.

\section{Distribution}

The species is known from Santa Catarina and São Paulo States in Brazil, where it was collected in Malaise- and light traps. Both collection sites have a humid, coastal climate with many small streams. The vegetation is a mosaic of primary and secondary forest and epiphytes are abundant.

\section{Pebapomberus euniceae sp. n. (Figures 11-15)}

Type material: Holotype male, Brazil: São Paulo: Parque Estadual Intervales, Iporanga, 24 ${ }^{\circ} 32^{\prime}$ S and 48 $42^{\prime}$ 'W, 26-27.x.2001, CDC trap, E.A.B. Galati (MZUSP).

Diagnostic characters: This species can be separated from $P$. rugendas $\mathrm{n}$. $\mathrm{sp}$. by the inferior volsella having a narrowly triangular, pointed anterior lobe and a broadly rounded apical lobe of the gonostylus.

Etymology: Named after Dr. Eunice A. B. Galati for making the material available to us.

\section{Description}

Male $(\mathrm{n}=1)$. Total length $2.00 \mathrm{~mm}$. Wing length $1.17 \mathrm{~mm}$. Total length/wing length 1.71. Wing length/length of profemur 2.44.

Coloration. Thorax, head, and coxae brown; abdomen, antennal flagellum and legs uniformly light brown.

Head. AR 0.88. Ultimate flagellomere $328 \mu \mathrm{m}$ long. Temporal setae 9 including 5 inner verticals and 4 outer verticals and 2 postorbitals. Clypeus with 7 setae. Tentorium, stipes, and cibarial pump as in Figure 11. Tentorium $118 \mu \mathrm{m}$ long, $20 \mu \mathrm{m}$ wide. Stipes $107 \mu \mathrm{m}$ long. Palp segment lengths (in $\mu \mathrm{m}$ ): $18,34,69,79,100$. Third palpomere with 3 sensilla clavata subapically, longest $12 \mu \mathrm{m}$ long.
Thorax (Figure 12). Antepronotum with 1 seta. Dorsocentrals 10; acrostichals 14 beginning close to antepronotum, composed of 5 anterior simple and 9 posterior scalpellate; prealars 4, 2 posterior and 2 anterior; supraalar 1. Scutellum with 7 setae.

Wing (Figure 13). VR 1.45. C extension $68 \mu \mathrm{m}$ long. Brachiolum with 1 seta, remaining veins and cells bare. Squama with 2 setae.

Legs. Spur of fore tibia $34 \mu \mathrm{m}$ long, spurs of mid tibia $16 \mu \mathrm{m}$ and $23 \mu \mathrm{m}$ long, spurs of hind tibia $14 \mu \mathrm{m}$ and $43 \mu \mathrm{m}$ long. Width at apex of fore tibia $25 \mu \mathrm{m}$, of mid tibia $27 \mu \mathrm{m}$, of hind tibia $36 \mu \mathrm{m}$. Comb with 11 setae, longest $32 \mu \mathrm{m}$, shortest $19 \mu \mathrm{m}$ long. Lengths and proportions of legs as in Table 2 .

Hypopygium (Figures 14-15). Tergite IX covered with microtrichia; laterosternite IX with 5 setae. Anal point wedge-shaped, $43 \mu \mathrm{m}$ long, $20 \mu \mathrm{m}$ wide at base, with 9 weak marginal setae. Phallapodeme $83 \mu \mathrm{m}$ long; transverse sternapodeme $84 \mu \mathrm{m}$ long. Virga $42 \mu \mathrm{m}$ long. Gonocoxite $150 \mu \mathrm{m}$ long. Gonostylus $70 \mu \mathrm{m}$ long (not including apical lobe); megaseta $14 \mu \mathrm{m}$ long. HR 2.13. HV 2.84.

\section{Distribution}

The species is known from southern São Paulo State in Brazil, where it was collected in a CDC trap during a project aimed at Phlebotominae. The locality is within a nature reserve with many small streams and rivulets. The vegetation is mainly pristine mountain forest with mosses and many different species of epiphytes.

\section{Acknowledgements}

We are indebted to Dr. Eunice A. B. Galati, Claudio G. Froehlich and Dr. Fabio O. Roque for making the new species available to us. Some slide preparations were made by Gladys C. A. Ramirez; the wings were drawn by Carla M. J. Lagos Diaz. The study was partially funded through the Brazilian Research Council of São Paulo State (FAPESP 11/50162-1) within the BIOTA-FAPESP - The Biodiversity Virtual Institute Program (www.biota.org.br) and the University Museum of Bergen, University of Bergen, Norway.

\section{References}

CRANSTON, P.S., OLIVER, D.R. \& SÆTHER, O.A. 1989. The adult males of Orthocladiinae (Diptera: Chironomidae) of the Holarctic region. Keys and diagnoses. In Chironomidae of the Holarctic region: Keys and diagnoses. Part 3. Adult males. (T. Wiederholm, ed.). Ent. Scand. Suppl. 34:165-352.

MENDES, H.F. \& ANDERSEN, T. 2008. A review of Antillocladius Sæther and Litocladius Mendes, Andersen et Sæther, with the description of two new Neotropical genera (Diptera, Chironomidae, Orthocladiinae). Zootaxa 1887:1-75. 
MENDES, H.F. \& PINHO, L.C. 2011. Taxonomy of Chironomidae (Insecta: Diptera) in Brazil. Brazilian Chironomid Home Page. http://sites.google. com/site/brazilianchironomids/ (último acesso em 22/12/2011).

MENDES, H.F., ANDERSEN, T. \& SÆTHER, O.A. 2004. New species of Ichthyocladius Fittkau, a member of the Corynoneura-group (Diptera: Chironomidae: Orthocladiinae), with a review of the genus. Stud. Neotrop. Fauna Environ. 39:15-35.

SÆTHER, O.A. 1969. Some Nearctic Podonominae, Diamesinae and Orthocladiinae (Diptera: Chironomidae). Bull. Fish. Res. Board Canada 107:1-154.
SÆTHER, O.A. 1980. Glossary of Chironomid morphology terminology (Diptera: Chironomidae). Ent. Scand. Suppl. 14:1-51.

SPIES, M. \& REISS, F. 1996. Catalog and bibliography of neotropical and Mexican Chironomidae (Insecta, Diptera). Spixiana, Suppl. 22:61-119.

SPIES, M., ANDERSEN, T., EPLER, J.H. \& WATSON JUNIOR, C.N. 2009. Chironomidae (Non-biting midges). In Manual of Central American Diptera (B.V. Brown, A. Borkent, J.M. Cumming, D.M. Wood, N.E. Woodley \& M.A. Zumbado, eds.). NRC Research Press, Ottawa, Canada, p.437-480. 